\title{
Clinic and immunohistochemical differentiation via cytokeratines of a renal adenocarcinoma in an eight-year-old Hanoverian gelding
}

\author{
David Lichtenberg' , Ina Holst ${ }^{2}$, Judith Winter ${ }^{3}$, Sven Kleinschmidt² and Monica Venner ${ }^{3}$ \\ 1..Tierklinik Hochmoor, Germany \\ 2 Tierärztliche Hochschule Hannover, Institut für Pathologie, Germany \\ 3 Klinik für Pferde Destedt, Germany
}

\begin{abstract}
Summary: Renal adenocarcinoma in horses are challenging to diagnose at an early stage. As horses with renal adenocarcinoma mainly show unspecific symptoms including ongoing weight loss and intermittent fever of unknown origin, neoplasms should be added to the list of differential diagnoses during evaluation of those patients. Via immunohistochemical staining of a biopsy/necropsy specimen of a neoplasia it is possible to track the tumors origin. Using immunohistochemical staining to proof the tumor's origin might be beneficial for making the decision to treat a horse surgically or euthanize it.
\end{abstract}

Keywords: horse / oncology / renal / adenocarcinoma / cytoceratines

Klinik und immunhistochemische Cytokeratin-Differenzierung eines renalen Adenokarzinoms bei einem 8-jährigen Hannoveraner Wallach

Eine ante-mortem Diagnose von renalen Adenokarzinomen beim Pferd ist schwierig zu stellen. Dies liegt unter anderem vor allem an den sehr unspezifischen Symptomen wie Gewichtsverlust und intermittierendem Fieber. Oft ist der Tumor zum Zeitpunkt der Diagnose schon metastasiert. Im vorliegenden Fall wurde beim Pferd eine Methode etabliert, die eine Zuordnung von tumorösem Gewebe zu seinem Ursprungsepithel ermöglicht. Mittels des immunhistochemischen Vergleichs der Zytokeratine des Tumors und des Organs kann evaluiert werden, ob das tumorös entartete Organ primär betroffen ist, oder ob es sich um Metastasen handelt. Im vorliegenden Fall konnte nachgewiesen werden, dass die Niere primär betroffen war. Wird ein solches renales Adenokarzinom rechtzeitig diagnostiziert und mittels Biopsie als Primärtumor identifiziert, könnte in solchen Fällen eine Nephrektomie in Erwägung gezogen werden.

Schlüsselwörter: Pferd / Onkologie / renal / Adenokarzinom / Zyłokeratine

Correspondence: Dr. David Lichtenberg, Tierklinik Hochmoor, von Braun Straße 10, 48712 Gescher-Hochmoor, E-Mail: david.lichtenberg@web.de

Citation: Lichtenberg D., Holst I., Winter J., Kleinschmidt S., Venner M. (2014) Renal Adenocarcinoma: Clinic and Immunohistochemical Differentiation via Cyłokeratines. Pferdeheilkunde 30, 291-296

\section{Introduction}

Renal adenocarcinomata in horses are rare (Brown 1985). They represent less than $1 \%$ of all equine neoplasms (Madewell 1987). This tumor mainly arises from the epithelium of the proximal convoluted tubules (Schott 2004). Due to nonspecific complaints such as poor performance, weight loss and depression a renal cell carcinoma is often a challenge to diagnose. A definitive antemortem diagnosis is only occasionally possible, because clinical symptoms become obvious at the moment the tumor has spread through the body (Traub et al. 1983). Even at necropsy the origin of the tumor might not be clearly detectable due to extension of metastases in the whole abdominal and thoracic cavity. In the past 35 years 27 cases of equine renal carcinoma were published in English peer-reviewed journals with a median survival rate of 11 days (Wise at al. 2009).

Cytokeratines are intermediate filament-forming proteins. They only occur in epithelia and supply their mechanical support. Different types of epithelia express different types of cytokeratines, which can be tested by immuno-histochemical stain. To the author's knowledge there is no literature on immuno-histochemical assays for tracing renal adenocarcinoma by using cytokeratines in veterinary medicine.

To help determining the origin of the primary tumor cytokeratines offer the possibility to better differentiate the origin of an epithelium. The treatment of choice for a one sided primary renal tumour is complete resection by nephrectomy (Wise et al. 2009). An earlier detection of the intra-abdominal tumor followed by a routinely performed immuno-histochemical staining of a renal biopsy could lead to an earlier diagnosis and possibly to a treatment option.

\section{Case history}

An 8-year-old Hanoverian dressage horse was presented with a significant weight loss within a week and showed a slightly distended abdomen. No signs of poor performance were noted; the week before the horse had performed at high level dressage. The horse was dewormed routinely every four month, the last time seven weeks before presentation. 


\section{Clinical findings}

At presentation the gelding had a body temperature of $38.6^{\circ} \mathrm{C}$. He had a heart rate of $44 / \mathrm{min}$. He presented cachectic with a slightly distended abdomen. At rectal examination multiple undefined masses were palpated; the largest one where one would expect the left kidney. A transcutaneous ultrasound examination of the complete abdomen revealed abnormal findings of the left kidney; parenchyma could not be detected; only an unstructured hyperechoic mass with focal hypoechoic spots (Fig. 1). An abnormal amount of peritoneal fluid was detectable via ultrasound of the ventral abdomen.

In a routine complete blood count (CBC) and biochemical profile the patient showed a hypoalbuminaemia $(21.3 \mathrm{~g} / \mathrm{l}$ $[25-54 \mathrm{~g} / \mathrm{l}])$, a mild leucocytosis $(11.6 \mathrm{G} / \mathrm{l}[5-10 \mathrm{G} / \mathrm{l}])$, increased LDH (1306.1 U/l $[<400 \mathrm{U} / \mathrm{l}$.$) , and a decrease in$ serumiron $(6.4 \mu \mathrm{mol} / \mathrm{l}[17.9-64.5 \mu \mathrm{mol} / \mathrm{l}])$. Calcium was $2.7 \mathrm{mmol} / \mathrm{l}[2.5-3.7 \mathrm{mmol} / \mathrm{l}]$. The serumproteine content was normal $(58.0 \mathrm{~g} / \mathrm{l}[55-75 \mathrm{~g} / \mathrm{l}])$. A serumprotein-electrophoresis was performed. It showed a monoclonal peak of the $\gamma$-globulin fraction. The analysis of creatinine and urea pres-

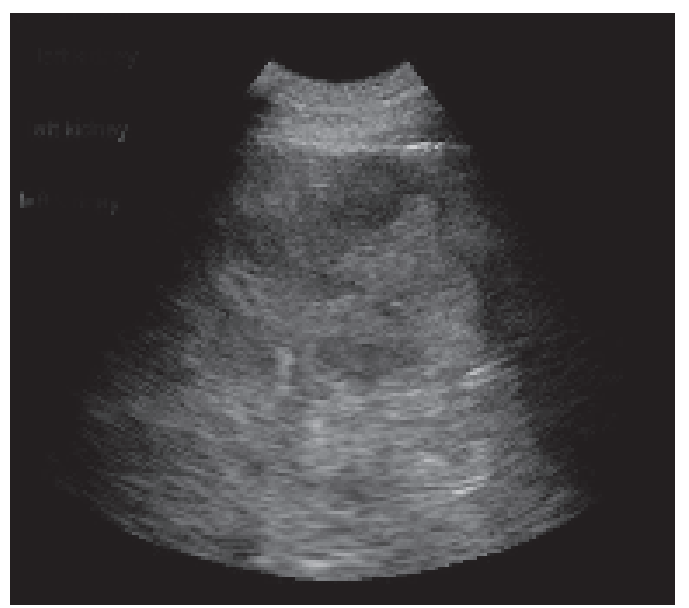

Fig. 1 Ultrasonographical appearance of the tumouros kidney

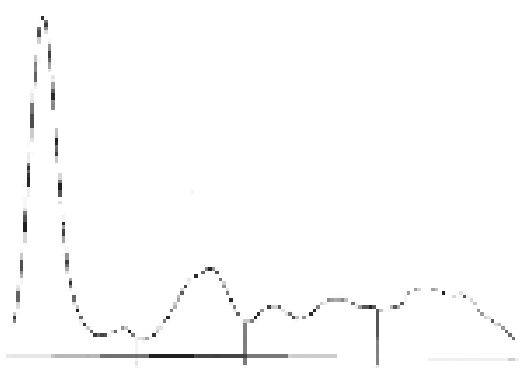

Fig. 2 Serum-protein-electrophoresis ented normal values $(88.8 \mu \mathrm{mol} / \mathrm{l}[71-159 \mu \mathrm{mol} / \mathrm{l}]$ and $5.3 \mathrm{mmol} / \mathrm{l}[3.3-6.7 \mathrm{mmol} / \mathrm{l}])$. The blood lactate level was $4.2 \mathrm{mmol} / \mathrm{l}[0.5-2.0 \mathrm{mmol} / \mathrm{l})$; the lactate dehydrogenase (LDH) $1306.1 \mathrm{U} / \mathrm{I}[<400 \mathrm{U} / \mathrm{l}]$. No hematuria or tumorous cells could be observed in a sediment-cytologie of the urine.

Abdominal fluid obtained by abdominocentesis was yellow colored and contained $42 \mathrm{~g} / \mathrm{L}$ total protein $[1-28 \mathrm{~g} / \mathrm{L}]$ and $12.6 \mathrm{G} / \mathrm{L}[2-5 \mathrm{G} / \mathrm{L}]$ leucocytes. The amount of peritoneal fluid coming out of the cannula gave suspicion that an ascites was present.

Based on the clinical findings an abdominal tumor in or around the left kidney was suspected such as lymphoma, mesothelioma or adenocarcinoma. As a differential diagnosis a granulomatous nephritis caused by Halicephalobus deletrix was considered. Because of the poor prognosis the horse was euthanized one day after referral. To differentiate the origin and nature of the tumor an autopsy was performed.

\section{Post mortem findings}

At necropsy the horse showed an abundant ascites of 30 liters. The left kidney was mostly replaced by a mass with an irregular surface. It measured about $40 \mathrm{~cm}$ in diameter and weighed $14,5 \mathrm{~kg}$ (Fig. 6). On cut section, the mass was cavitated, gray-white to reddish and had a soft consistency. At the periphery, well circumscribed remnants of kidney tissue were present. Additional masses (up to $15 \mathrm{~cm}$ in diameter) were located in spleen, liver, omentum majus, diaphragm and in the pulmonary and the subiliac lymph nodes. Invasion into the thoracic cavity via the diaphragm was seen.

Histologically, within the neoplastic mass there was a densely cellular, well demarcated, multilobular, infiltrative and encapsulated mass. Cells were closely packed in elongated, irregular tubules and acini, arranged in 2-3 layers with mild to moderate amount of fibrovascular stroma. They were polygonal to columnar, measured $11 \times 6 \mu \mathrm{m}$, with indistinct cell borders, and had a scant amount of fibrillar, eosinophilic cytoplasm. The nucleus was elongated, centrally located, and showed coarsely stippled, basophilic chromatin with one to two basophilic nucleoli (Fig. 3). There was a mild anisocytosis and-karyosis with zero to one mitoses per high power field. Necrosis, haemorrhage and mineralization were detected in the central area of the mass. Remnants of the left kidney exhibited moderate interstitial inflammation and fibrosis, dilation of tubules, and loss of tubular epithelium.

Based on the morphological appearance and distribution a diagnosis of a renal adenocarcinoma was made. In addition, the right kidney demonstrated dilation of Bowman's capsule

\begin{tabular}{lllll}
\hline Tab. 1 Serum-proteine electrophoresis & & & \\
\hline Total protein (TP) & $58 \mathrm{~g} / \mathrm{l}$ & $55-75$ & $\mathrm{~g} / \mathrm{l}$ \\
\hline Albumin (A) & $40.5 \%$ & $45-60$ & $\%$ \\
TP/A quotient & 0.68 & $0.7-1.1$ & \\
$\alpha$-globulin & $17.9 \%$ & $10-20$ & $\%$ & \\
$\beta$-globulin & $19.3 \%$ & $10-25 \%$ & \\
$\gamma$-globulin & $22.3 \%+\frac{1}{2} \%$ & $8-22 \%$ & \\
\hline
\end{tabular}


with extravasation of proteinaceous fluid. Furthermore, a lympho-plasmacytic pleuritis, a multinodular fibrosis of the lung, a focal ulcerative to suppurative gastritis and pituitary cysts were diagnosed.

To specify the cellular origin of the renal neoplasia immunohistochemistry was performed with a panel of murine monoclonal antibodies (all from Dako Deutschland, Hamburg, Germany unless otherwise stated) specific for the following molecules: vimentin and different cytokines (Table 1) (Kummerfeld et al. 2008). The antibodies were used by following standard avidin-biotin-peroxidase complex (ABC) method. For enzyme localization, 3,3' diaminobenzidinhydrochloride (DAB) and 3-amino-9-ethylcarbazole (AEC) were used as substrates. Counterstaining was done with haematoxylin. Equine epidermis and mammary gland were used as positive

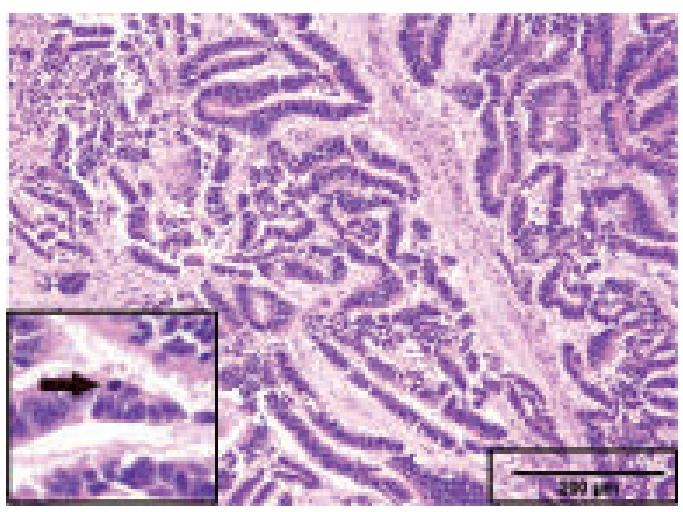

Fig. 3 Renal adenocarcinoma with columnar neoplastic cells arranged in elongated irregular tubules. Hematoxylin-Eosin staining. Inset: higher magnification (400x) of tumor cells with a mitotic figure (arrow).

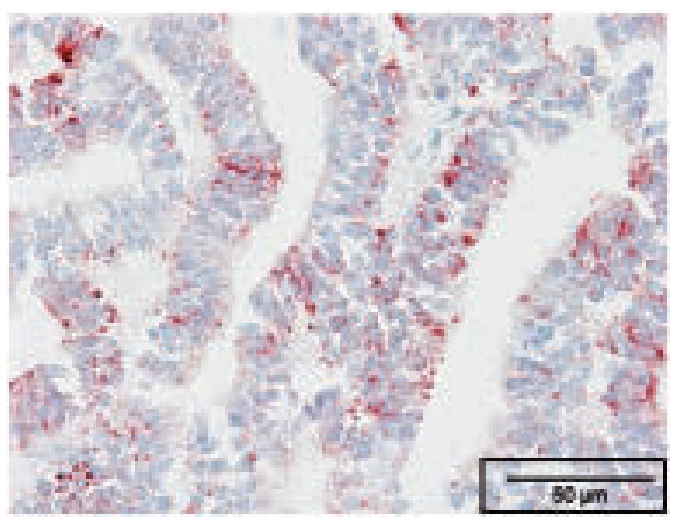

Fig. 4 Renal adenocarcinoma. Intracytoplasmic labelling for cytokeratin AE1/AE3 in neoplastic cells. controls. The immunhistochemical results were summarized in table 2.

The antibody AE 1/AE3, specific for CK 1-8, 10, 13-16 and 19, and the antibody MNF 1 16, specific for CK 5, 6 and 18 produced a cytoplasmic staining of variable intensity in the tumor cells, in the epithelium of the proximal and distal tubules and in the epithelium of the collecting ducts of the nonneoplastic kidney. The remaining antibodies for CK did not show any labelling in neoplastic or non-neoplastic kidney (Fig. 4). The antibody for vimentin labelled multifocally small vessels and capillaries of the non-neoplastic kidney, and fibroblasts within the fibrous capsule of the neoplasm.

\section{Discussion}

Adenocarcinomata are malignant neoplasia arising mainly from the glandular epithelium. They are defined by the pre-

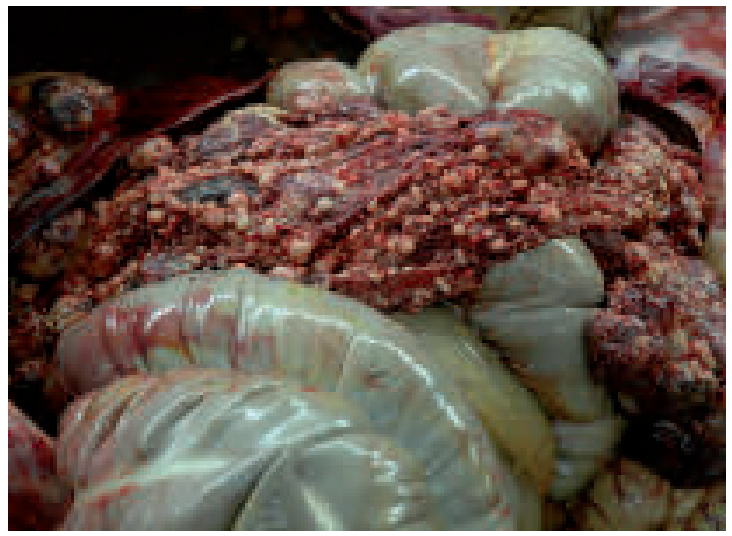

Fig. 5 Tumor implants located in omentum majus and spleen.

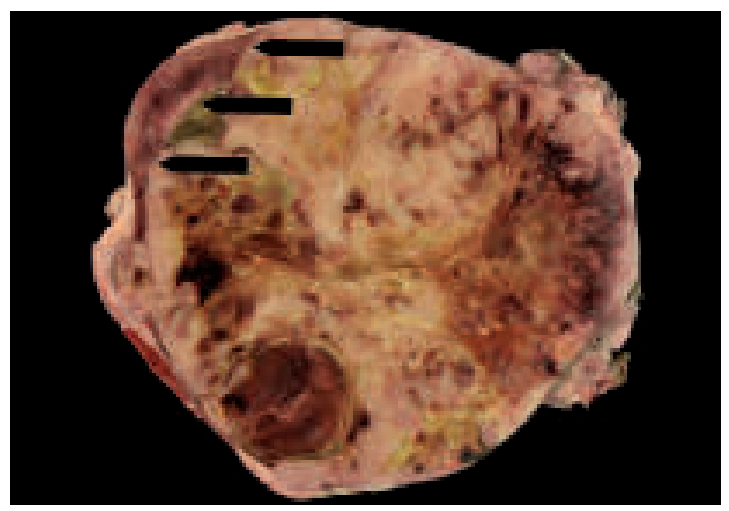

Fig. 6 Renal adenocarcinoma. Arrows: remnants of kidney.

Table 2 Antibodies (Dako Deutschland GmbH, Hamburg), Dilution, Positive Controls and Immunohistochemical results. ' Citrate buffer, microwave 20 minutes; ${ }^{2}$ Pronase 20 minutes;

\begin{tabular}{|c|c|c|c|c|c|}
\hline \multirow[b]{2}{*}{ Marker/Clone } & \multirow[b]{2}{*}{ Cytokeratin } & \multirow[b]{2}{*}{ Dilution } & \multirow[b]{2}{*}{ Positive Control } & \multicolumn{2}{|c|}{ Immunohistochemical Reactivity } \\
\hline & & & & Kidney & Carcinoma \\
\hline $\mathrm{D} 5 / 16 \mathrm{~B} 4$ & 5,6 & $1: 100^{1}$ & Epidermis & - & - \\
\hline OV-TL 12/30 & 7 & $1: 100^{1}$ & Mamma & - & - \\
\hline DE-K10 & 10 & $1: 100^{1}$ & Epidermis & - & - \\
\hline $34_{\beta} \mathrm{E} 12 \mathrm{M} 0630$ & $1,5,10,14$ & $1: 500^{1}$ & Mamma & - & - \\
\hline AE $1 / A E 3$ & $1-8,10,13-16,19$ & $1: 500^{2}$ & Epidermis & + & + \\
\hline MNF116 & $5,6,18$ & $1: 2500^{2}$ & Epidermis & + & + \\
\hline
\end{tabular}


sence of new and uncontrolled cellular growth and their glandular appearance. Since renal neoplasms in general and adenocarcinoma in particular are rare in horses, they are not on the top of the list of differentials facing a patient with exercise intolerance, weight loss and fever. Although in all species age in general increases the risk of neoplasia, adenocarcinomata in the horse emerge regardless of the age (Mair 2009), which increases the diagnostical challenge of this condition.

Therefore even in a young horse with non-specific symptoms like weight loss, depression, recurrent colic and intermittent fever, one should be aware of the possibility of a neoplasmbased disease. In those cases the use and interpretation of a wide variety of diagnostic tools is indicated, such as evaluating the body temperature: $22 \%$ of fevers of an unknown origin that last for three weeks or more are due to neoplasms (Dinarello et al. 1996). Evaluation of the body weight is essential; neoplastic activity causes an increased rate of protein and energy use that leads to a quick weight loss.

Laboratory analysis of blood (albumin, serum-protein-electrophoresis (Fig.2 and Tab. 1), creatinine and urea) can be indicative of a neoplastic disorder (Deegen at al. 2000). In cases involving neoplastic tissue often a serum-hypoalbuminaemia and leucocytosis occurs. Those findings are due to the increased protein use and chronic inflammation. Increased globulins may suggest an inflammatory process and neoplasia, like it is shown as a peak in the -fraction in Fig.2 and Tab. 1.

Creatinine and urea might present at a normal range, since renal adenocarcinoma usually are unilateral and therefore the contralateral kidney keeps up normal renal function.

The presence of neoplastic cells in the urine indicates neoplastic tissue in the urinary tract. If there is proof of neoplastic cells in urine (evaluated by sediment cytology) and abdominal fluid there should be a strong suspicion of metastases into the abdominal cavity and a surgical intervention is probably useless.

An interesting phenomenon is the increased amount of blood lactate and LDH. Reasons for hyperlactatemia may be tissue hypoxia secondary to an insufficient tissue perfusion, increased release of lactate from the gut, as well as anemia (McGovern et al. 2011). In contrast to that, Walenta et al. (2004) found, that LDH was upregulated in most tumors compared to surrounding normal tissue.

Marcanato et al. (2009) showed a correlation between lymphoma in dogs and an increased serumlactate concentration and LDH activity. Those findings (often accompanied by a hypercalcaemia, due to a tumor-related expression of parathormon-related protein) are summarized as paraneoplastic syndrome (Bergmann et al. 2012).

The patterns of cytokeratines we evaluated matched comparing the kidney and the neoplastic tissue. One has to consider, that although cytokeratines are not extremely likely to perform mutation in neoplastic cells due to the fact that they are a conserved part of the cytoskeleton, it might be possible that neoplastic tissue of other organs express similar patterns due to mutation. As more cytokeratin-patterns are compared, as more likely it is to trace the tumor specifically. Cytokeratin
20 for example might be interesting to look at in the future, since it is not expressed in primary renal tumors in humans (Deshmukh et al. 2011).

As the antibodies in this case show a resilient positive control as well as a significant congruency in organ and neoplastic tissue we assume, that the method of immunohistochemical staining of cytokeratines is able to trace a primary renal adenocarcinoma to its origin by cytokeratin-differentiation.

Since we established this method in the horse, it should be possible now to do the same procedure with a biopsy specimen. If there is no evidence of metastases by using the diagnostic tools discussed earlier and immune-histochemistry proofs the renal origin the surgeon could be sure to operate on the primary neoplasm and perform a nephrectomy. That is why immunhistochemistry may be another helpful tool to differentiate the tumour's origin and help making the decision to euthanize a horse or to dare a surgical treatment.

\section{References}

Bergman P. J. (2012) Paraneoplastic hypercalcemia. Top. Companion. Anim. Med. 27, 156-158, doi: 10.1053/i.tcam. 2012. 09.003

Brown C. M. (1986) Equine nephrology. Vet. Ann. 26

Cotchin E. (1977) A general survey of tumors in the horse. Equine Vet. J. 9, 16

Deegen E., Venner M. (2000) Diagnostik des Magenkarzinoms beim Pferd. Dtsch. Tierärztl. Wschr. 107, 472-476

Deshmukh M. K. (2011) Composite epithelial kidney tumor comprising of adeno and neuroendocrine carcinomatous components: an unusual variant of renal cell carcinoma. Indian J. Pathol. Microbiol. 54, 809-813. doi: 10.4103/0377-4929.91528

Dinarello C. A. (1996) Thermoregulationand the pathogenesis of fever. Infect. Dis. Clin. North Am. 10, 433-450

Kummerfeld M., Knieriem A., Wohlsein P. (2008) Osteomyelitis and papillary renal adenoma in a red panda (Ailurus fulgens fulgens)]. Dtsch. Tierarztl. Wschr. 115, 421-425

Madewell B. R., Theilen G. H. (1987) Tumors of the urogenital tract. 1. Tumors of the urinary tract. In: Theilen G. H., Madewell B. R., editors: Veterinary cancer medicine, ed 2, Philadelphia, 1987, Lea \& Febiger

Mair T. (2009) Neoplasia in the geriatric horse. In: Proceedings of the 48th British Equine Veterinary Association Congress BEVA Sep. 9-12, 2009 Birmingham, United Kingdom

Marconato L., Crispino G., Finotello R. (2009) Serum lactate dehydrogenase activity in canine malignancies. Vet. Comp. Oncol. 7, 236-243

McGovern K. F., Lascola K. M., Davis E., Fredrickson R. L., Tan R. (2011) T-Cell Lymphoma with Immune-Mediated Anemia and Thrombocytopenia in a Horse. J. Vet. Intern. Med. 25, 1181 - 1185

Schott H. C. (2004) Neoplasia of the urinary tract. In: Equine internal medicine 2nd edn., 2004 Ed. S M. Reed, Saunders, pp 1287. 1289

Sundberg J. P., Burnstein T., Page E. H. (1977) Neoplasm of equidae. J. Am. Vet. Med. Assoc. 170, 150

Traub J. L., Bayly W. M., Reed S. M. (1983) Intraabdominal neoplasia as a course of chronic weight loss in the horse. Comp. Cont. Educ. Pract. Vet. 5, 526

van Amstel S. R., Huchzermeyer D., Reyers F. (1984) Primary renal cell carcinoma in a horse. J. South Afr. Vet. Assoc. 55, 35-38

Walenta S., Schroeder T., Mueller-Klieser W. (2004) Lactate in solid malignant tumors: Potential basis of a metabolic classification in clinical oncology. Curr. Med. Chem. 11, 2195-2204 


\section{Einführung}

Renale Adenokarzinome stellen beim Pferd eine seltene Erkrankung dar (Brown 1985). Sie repräsentieren weniger als $1 \%$ aller Neoplasien beim Pferd (Madewell 1987). Der Tumor entsteht hauptsächlich aus dem Epithel der proximalen Tubuli (Schott 2004). Durch unspezifische Symptome wie Leistungsdefizite, Gewichtsverlust und Depression stellt die Diagnose von renalen Adenokarzinomen oft eine große Herausforderung dar. Eine endgültige Diagnose ist prämortal nur gelegentlich möglich, da die klinischen Symptome oft erst auftreten, wenn der Tumor bereits metastasiert ist (Traub et al. 1983). Auch in der Obduktion ist der Ursprung des Tumors aufgrund der starken Metastasierung in Bauch-und Brusthöhle nicht immer sicher nachweisbar. In den letzten 35 Jahren wurden weltweit 27 Fälle von equinen renalen Karzinomen mit einer mittleren Überlebensrate von 11 Tagen in englischssprachigen Peer-Review-Zeitschriften veröffentlicht (Wise et al. 2009).

Zytokeratine sind intermediäre filamentformende Strukturproteine des Zytoskeletts der eukaryonten Zelle. Sie treten ausschließlich im Epithel auf und unterstützen dessen Stützfunktion. Verschiedene Epithelien exprimieren verschiedene Zyłokeratintypen, die mittels immunohistologichen Färbungen differenziert werden können. Soweit es den Autoren bekannt ist, gibt es keine Literatur bezüglich immunohistologischer Untersuchungen zur Tumorgewebedifferenzierung von equinen renalen Adenokarzinomen. Indem sie die Möglichkeit bieten, die Herkunft eines Epithels genaver zu differenzieren, können Zytokeratine dabei helfen, den Ursprung des Primärtumors bestimmen. Die Behandlung der Wahl für einen einseitigen Nierentumor ist die vollständige Resektion im Sinne einer Nephrektomie (Wise et al. 2009). Eine frühere Erkennung des intraabdominalen Tumors, gefolgt von einer routinemäßig durchgeführten immunohistochemischen Färbung eines renalen Bioptats könnte zu einer früheren Diagnose und somit zu einer eventuellen Behandlungsmöglichkeit verhelfen.

\section{Fallbericht}

Ein achtiähriges Hannoveraner Dressurpferd wurde aufgrund erheblichen Gewichtsverlusts innerhalb einer Woche einhergehend mit einem leicht aufgetriebenen Abdomen vorgestellt. Ein Leistungsabfall wurde nicht festgestellt, in der vorangegangenen Woche hatte das Pferd Dressurleistungen auf hohem Niveau gezeigt. Das Pferd wurde regelmäßig im Abstand von vier Monaten entwurmt, zuletzt sieben Wochen bevor es vorgestellt wurde.

\section{Klinisches Bild}

Bei der Untersuchung lag die Körpertemperatur des Wallachs bei $38,6^{\circ} \mathrm{C}$. Die Herzfrequenz betrug 44/min. Das Pferd war kachektisch und zeigte ein leicht aufgetriebenes Abdomen. Bei der rektalen Untersuchung wurden zahlreiche unbestimmte Raumforderungen palpiert, die größte im Bereich der linken Niere. Die transkutane Ultraschalluntersuchung des gesamten Abdomens ergab einen anormalen Befund an der linken Niere. Es konnte kein Parenchym dargestellt werden, sondern nur eine unstrukturierte hyperechogene Masse mit fokalen hypoechogenen Punkten (Fig. 1). Im Ultraschallbild des ventralen Abdomens wurde eine erhöhte Menge an Peritonealflüssigkeit festgestellt.
In einem routinemäßig erhobenen großen Blutbild und biochemischen Profil zeigte der Patient eine Hypoalbuminämie $(21,3 \mathrm{~g} / \mathrm{l}[25-54 \mathrm{~g} / \mathrm{l}])$, eine leichte Leukozytose $(11,6 \mathrm{~g} / \mathrm{l}$ $[5-10 \mathrm{~g} / \mathrm{l}])$, einen erhöhten LDH-Wert $(1306,1 \mathrm{U} / \mathrm{I}$ $[<400 \mathrm{U} / \mathrm{I})$ und ein erniedrigtes Serumeisen $(6,4 \mu \mathrm{mol} / \mathrm{I}$ $[17,9-64,5 \mu \mathrm{mol} / \mathrm{l}])$. Der Kalziumwert lag bei $2,7 \mathrm{mmol} / \mathrm{l}$ $[2,5-3,7 \mathrm{mmol} / \mathrm{l}]$. Der Serumproteingehalt war im Normbereich $(58,0 \mathrm{~g} / \mathrm{l}[55-75 \mathrm{~g} / \mathrm{l}])$. Es wurde eine SerumproteinElektrophorese durchgeführt. Diese zeigte einen monoklonalen Peak der $\gamma$-Globulin-Fraktion. Die Bestimmung von Kreatinin und Harnstoff ergab normale Werte $(88,8 \mu \mathrm{mol} / \mathrm{I}$ [71-159 $\mathrm{mol} / \mathrm{l}]$ und $5,3 \mathrm{mmol} / \mathrm{l}[3,3-6,7 \mathrm{mmol} / \mathrm{l}])$. Der Laktatwert im Blut lag bei 4,2 mmol// [0,5-2,0 mmol/l), der Wert für Laktatdehydrogenase (LDH) bei 1306, 1 U/I [<400 U/I]. In einer Harnsediment-Zytologie konnten keine Hämaturie oder Tumorzellen nachgewiesen werden.

Aufgrund der klinischen Befunde wurde die Verdachtsdiagnose eines abdominalen Tumors wie eines Lymphoms, Mesothelioms oder Adenokarzinoms im Bereich der linken Niere erhoben. Als Differentialdiagnose wurde eine durch Halicephalobus deletrix verursachte granulomatöse Nephritis in Erwägung gezogen. Wegen der schlechten Prognose wurde das Pferd einen Tag nach der Überweisung euthanasiert. Um den Ursprung und die Beschaffenheit des Tumors festzustellen wurde eine Autopsie durchgeführt.

\section{Postmortale Befunde}

Bei der Autopsie des Pferdes wurde ein massiver Aszites von 30 Litern festgestellt. Die linke Niere war größtenteils durch eine Raumforderung mit unregelmäßiger Oberfläche verdrängt. Diese maß etwa $40 \mathrm{~cm}$ im Durchmesser und hatte ein Gewicht von $14,5 \mathrm{~kg}$ (Fig. 6). Im Sektionsschnitt erschien die Raumforderung kavernös, grau-weiß bis rötlich und von weicher Konsistenz. In der Peripherie waren gut umschriebene Bereiche verbliebenen Nierengewebes vorhanden (Fig. 5). Weitere Raumforderungen (bis zu $15 \mathrm{~cm}$ im Durchmesser) befanden sich in Milz, Leber, Omentum majus, Diaphragma und in den pulmonalen und subilealen Lymphknoten. Eine Ausbreitung in die Brusthöhle über das Diaphragma wurde festgestellt.

Histologisch zeigte sich innerhalb der neoplastischen Raumforderung eine verkapselte, gut demarkierte, multilobulare, infiltrative dichte Zellmasse. Die Zellen erschienen dicht gedrängt in verlängerten, unregelmäßigen Tubuli und Acini in 2-3 Schichten mit einer geringen bis mittleren Menge an fibrovaskulärem Stroma. Sie waren polygonal bis säulenförmig mit einem Maß von $11 \times 6 \mu$ m mit undeutlichen Zellgrenzen und wiesen eine geringe Menge an fibrillärem, eosinophilem Zytoplasma auf (Fig.3). Der Zellkern war von länglicher Form, zentral in der Zelle lokalisiert und zeigte grobe Tüpfelung basophilen Chromatins mit ein bis zwei basophilen Nucleoli. Es bestand eine leichte Anisozytose und -karyose mit 0-1 Mitosen pro Hauptgesichtsfeld. Im zentralen Bereich der Raumforderung waren Nekrose, Hämorrhagie und Mineralisierung erkennbar. Überreste der linken Niere wiesen mittelgradige interstitielle Entzündung und Fibrose sowie Dilatation der Tubuli und Verlust des tubulären Epithels auf.

Aufgrund des morphologischen Erscheinungsbildes und Ausbreitung wurde die Diagnose eines renalen Adenokarzinoms gestellt. Zusätzlich zeigte sich an der rechten Niere eine Dila- 
tation der Bowman-Kapsel mit Extravasation proteinhaltiger Flüssigkeit. Weiterhin wurden eine lymphoplasmazelluläre Pleuritis, eine multinoduläre Lungenfibrose, eine fokale ulzerative bis eitrige Gastritis sowie hypophysäre Zysten festgestellt.

Um den zellulären Ursprung der renalen Neoplasie genaver zu bestimmen, wurde eine Immunohistochemie mit einem Panel muriner monoklonaler Antikörper (alle von Dako Deutschland, Hamburg, soweit nicht anders angegeben) spezifisch für Vimentin und verschiedene Cytokine (Tabelle 2) (Kummerfeld et al. 2008) durchgeführt. Die Antikörper wurden gemäß der Avidin-Biotin-Komplex (ABC)-Standardmethode verwendet. Für die Enzymbestimmung wurden 3,3'-Diaminobenzidinhydrochlorid (DAB) und 3-Amino-9-Ethyl-Carbazol (AEC) als Substrate verwendet. Die Gegenfärbung wurde mit Hämatoxylin durchgeführt. Equines Epidermis- und Milchdrüsengewebe dienten als Positivkontrolle. Die Ergebnisse der Immunohistochemie sind in Tabelle 2 zusammengefasst.

Die Antikörper AE1/AE3, spezifisch für CK 1-8, 10, 13-16 und 19, und MNF 116, spezifisch für CK 5, 6 und 18 erzeugten eine zytoplasmatische Färbung von wechselnder Stärke in den Tumorzellen, im Epithel der proximalen und distalen Tubuli und im Epithel der Sammelröhrchen der nicht neoplastischen Niere (Fig. 4). Die verbleibenden CK-spezifischen Antikörper ergaben weder in der neoplastischen noch in der nicht entarteten Niere eine Markierung. Der Antikörper für Vimentin markierte multifokal kleine Gefäße und Kapillaren der nicht neoplastischen Niere sowie Fibroblasten innerhalb der fibrösen Kapsel der Neoplasie.

\section{Diskussion}

Adenokarzinome sind maligne Neoplasien, welche vorwiegend aus dem Drüsenepithel entstehen. Sie werden über das Vorhandensein neven und unkontrollierten Zellwachstums und ihr glanduläres Erscheinungsbild definiert. Da renale Neoplasien im Allgemeinen und Adenokarzinome im Besonderen bei Pferden nur selten vorkommen, zählen sie nicht unbedingt zu den ersten Differentialdiagnosen bei Patienten mit Belastungsintoleranz, Gewichtsverlust und Fieber. Obwohl ein höheres Alter bei allen Tierarten das allgemeine Risiko einer Neoplasie erhöht, treten Adenokarzinome beim Pferd unabhängig vom Alter auf (Mair 2009), was die diagnostische Herausforderung dieser Erkrankung noch erhöht. Daher sollte man auch bei einem jungen Pferd mit unspezifischen Symptomen wie Gewichtsverlust, Abgeschlagenheit, rezidivierender Kolik und intermittierendem Fieber die Möglichkeit einer Neoplasie als Ursache der Erkrankung in Erwägung ziehen. In diesen Fällen ist die Verwendung und Interpretation einer Vielzahl diagnostischer Maßnahmen indiziert, wie etwa die Auswertung der Körpertemperatur: 22\% der Fälle mit Fieber unbekannter Genese, welches über drei Wochen oder länger besteht, werden durch Neoplasien verursacht (Dinarello et al. 1996). Die Beurteilung des Körpergewichts ist unerlässlich, da neoplastische Aktivität einen vermehrten Protein- und Energieverbrauch verursacht, welcher zu einem raschen Gewichtsverlust führt.

Laboranalysen des Blutes (Albumin, Serumprotein-Elektrophorese [Fig. 2 und Tab. 1], Kreatinin und Harnstoff) können Hinweise auf eine neoplastische Erkrankung liefern (Deegen at al. 2000). Bei vorhandenem neoplastischem Gewebe treten häufig eine Serum-Hypoalbuminämie und eine Leukozy- tose auf. Diese Befunde ergeben sich aus dem erhöhten Proteinverbrauch und der chronischen Entzündung. Erhöhte Globulinwerte könnten auf einen entzündlichen Prozess und Neoplasie hinweisen, wie der Peak in der $\gamma$-Fraktion in Fig. 2 und Tab. 1 zeigt.

Kreatinin und Harnstoff können im Normbereich liegen, da renale Adenokarzinome üblicherweise unilateral auftreten und daher die kontralaterale Niere die normale renale Funktion aufrechterhält. Das Vorhandensein neoplastischer Zellen im Harn weist auf neoplastisches Gewebe in den Harnwegen hin. Wenn neoplastische Zellen in Harn (mittels SedimentZytologie) und Peritonealflüssigkeit nachgewiesen werden besteht der dringende Verdacht, dass Metastasen in der Bauchhöhle vorhanden sind und ein chirurgischer Eingriff somit wahrscheinlich aussichtslos wäre.

Die erhöhten Laktat- und LDH-Werte im Blut stellen eine interessante Erscheinung dar. Als Ursache für die Hyperlaktatämie kommen Gewebehypoxie infolge einer nicht ausreichenden Gewebeperfusion, erhöhte Laktatausschüttung aus dem Darm sowie Anämie infrage (McGovern et al. 2011). Dagegen stellten Walenta et al. (2004) fest, dass LDH in den meisten Tumoren im Vergleich zum umliegenden normalen Gewebe erhöht war.

Marcanato et al. (2009) bewiesen eine Korrelation zwischen Lymphomen bei Hunden und einer erhöhten SerumlaktatKonzentration sowie LDH-Aktivität. Diese Befunde (oft einhergehend mit einer Hyperkalzämie aufgrund einer tumorbedingten Expression eines parathormonähnlichen Proteins) werden als paraneoplastisches Syndrom zusammengefasst (Bergmann et al., 2012).

Die von uns ausgewerteten Zytokin-Muster stimmten im Vergleich des Nieren- und neoplastischen Gewebes überein. Es muss in Erwägung gezogen werden, dass neoplastisches Gewebe anderer Organe möglicherweise aufgrund von Mutationen ähnliche Muster exprimiert, obwohl es wenig wahrscheinlich ist, dass Zytokeratine in neoplastischen Zellen mutieren, da sie ein konservierter Bestandteil des Zytoskeletts sind. Je mehr Zytokeratin-Muster verglichen werden, desto wahrscheinlicher wird es, dass ein Tumor genau lokalisiert werden kann. Zytokeratin 20 könnte für zukünftige Betrachtungen interessant sein, da es beim Menschen nicht in renalen Primärtumoren exprimiert wird (Deshmukh et al. 2011). Da die Antikörper in diesem Fall sowohl eine belastbare Positivkontrolle als auch eine signifikante Kongruenz in Organ- und neoplastischem Gewebe aufweisen, gehen wir davon aus, dass die Methode der immunohistologischen Färbung von Zyłokeratinen geeignet ist, ein renales Adenokarzinom mittels Zyłokeratin-Differenzierung zu seinem Ursprung zu verfolgen. Nachdem wir die Eignung dieser Methode am Pferd belegen konnten, sollte dasselbe Verfahren auch für eine Biopsieprobe angewendet werden können. Wenn die oben besprochenen Diagnosewerkzeuge keine Hinweise auf Metastasen ergeben und die Immunhistochemie den renalen Ursprung des Tumors bestätigt, könnte der Operateur sicher sein, bei einer Nephrektomie den Primärtumor zu entfernen. Daher könnte die Immunohistochemie ein weiteres nützliches Verfahren darstellen, um den Ursprung eines Tumors zu differenzieren und die Entscheidung zwischen Euthanasie und dem Versuch einer chirurgischen Therapie zu erleichtern. 